\title{
Letter to the editor Re: Pan et al. "LLY17, a novel small molecule STAT3 inhibitor induces apoptosis and suppresses cell migration and tumor growth in triple-negative breast cancer"
}

\author{
Renba Liang ${ }^{1}(\mathbb{D}$
}

Received: 25 July 2020 / Accepted: 31 July 2020 / Published online: 14 August 2020

(c) Springer Science+Business Media, LLC, part of Springer Nature 2020

To the editor,

We read with great interest the paper by Pan et al. "LLY17, a novel small molecule STAT3 inhibitor induces apoptosis and suppresses cell migration and tumor growth in triplenegative breast cancer" [1] published in the latest issue of Breast Cancer Research and Treatment. We would like to congratulate Pan et al. for designing a novel small molecule STAT3 inhibitor (LLY17) that can inhibit growth of triplenegative breast cancer. LLY17 may provide a new candidate for triple-negative breast cancer treatment. There are, however, issues raised in this paper that are worthy of comment and attention.

In Fig. 3b, SUM159 cells were transfected with Control siRNA or STAT3 siRNA. The authors found that cell viability of Control siRNA decreased to nearly $50 \%$ after treatment with LLY17 $(0.25$ or $1 \mu \mathrm{M})$ for $48 \mathrm{~h}$. However, the authors claimed that LLY17-treated cells showed significant inhibition of cell migration in SUM159 cells without obvious changes of cell viability, which was almost up to $100 \%$ after treatment with higher concentrations $(2.5$ or $5 \mu \mathrm{M})$ of LLY 17 for $42 \mathrm{~h}$ (Fig. 5c). Although Control siRNA SUM159 cells and SUM159 cells, $42 \mathrm{~h}$ and $48 \mathrm{~h}$ were not exactly the same, the cell viability in high concentration group should not be higher than that in low concentration group. The similar phenomenon also occurred in MDA-MB-231 cells. These results confused us.
Yours sincerely, Renba Liang Ph.D.

Guangxi Medical University Cancer Hospital

Funding This study was not funded by any funding.

\section{Compliance with ethical standards}

Conflict of interest The author declares that he has no conflict of interest.

Research involving human participants and/or animals This article does not contain any studies with human participants or animals performed by any of the authors.

\section{Reference}

1. Pan L, Chen X, Fu S, Yu W, Li C, Wang T, Lo HW, Lin J (2020) LLY17, a novel small molecule STAT3 inhibitor induces apoptosis and suppresses cell migration and tumor growth in triplenegative breast cancer. Breast Cancer Res Treat 181(1):31-41

Publisher's Note Springer Nature remains neutral with regard to jurisdictional claims in published maps and institutional affiliations.

This comment refers to the article available online at https://doi. org/10.1007/s10549-020-05613-6.

Renba Liang

liangrenba@stu.gxmu.edu.cn

Department of Radiation Oncology, Guangxi Medical

University Cancer Hospital, No. 71 He Di Road,

Nanning 530021, Guangxi, People's Republic of China 